\title{
Prognostic Significance of BMI-1 But Not MEL-18 Expression in Pulmonary Squamous Cell Carcinoma
}

\author{
SOSEI ABE ${ }^{1}$, SHIN-ICHI YAMASHITA ${ }^{1}$, SO MIYAHARA ${ }^{1}$, JUNICHI WAKAHARA ${ }^{1}$, LEONA YAMAMOTO $^{1}$, \\ RYO MORI ${ }^{1}$, NAOKO IMAMURA ${ }^{1}$, YASUHIRO YOSHIDA ${ }^{1}$, RYUICHI WASEDA $^{1}$, \\ MASAFUMI HIRATSUKA ${ }^{1}$, TAKESHI SHIRAISHI ${ }^{1}$, KAZUKI NABESHIMA $^{2}$ and AKINORI IWASAKI ${ }^{1}$ \\ ${ }^{1}$ Department of General Thoracic, Breast and Pediatric Surgery, Faculty of Medicine, \\ Fukuoka University, Fukuoka, Japan; \\ ${ }^{2}$ Department of Pathology, Fukuoka University Hospital, Fukuoka, Japan
}

\begin{abstract}
Aim: We investigated the possibility of BMI-1 and MEL-18 to predict survival in patients with pulmonary squamous cell carcinoma. Materials and Methods: One hundred and ninety-nine patients underwent surgery in our Institute between 1995 and 2005. We used immunohistochemical (IHC) analysis to determine the expressions of BMI- 1 and MEL-18 and compared them with clinicopathological factors and survival. Results: Forty-one of 199 cases (21\%) were BMI-1-positive. No correlation was found between BMI-1 and MEL-18 expression by IHC and clinicopathological factors. Five-year overall survival in the BMI-1-positive group (66.8\%), but not MEL-18, was significantly better than that in the negative group $(45.5 \%$, $p=0.04$ ). In multivariate analysis, positive BMI-1 was a better prognostic factor of overall survival (hazard ratio $(H R)=0.561,95 \%$ confidence interval $(C I)=0.271-1.16$, $p=0.12)$. Conclusion: BMI-1 expression, but not MEL-18, is associated with a favorable prognosis and is a possible prognostic factor of pulmonary squamous cell carcinoma.
\end{abstract}

Lung cancer is the major cause of malignancy-related death worldwide (1). Approximately, $85 \%$ of lung cancer is nonsmall cell lung cancer (NSCLC) and the most frequently diagnosed histologies are adenocarcinoma and squamous cell carcinoma. Although adenocarcinoma is becoming more well-characterized, driver mutations of epidermal growth factor receptor (EGFR) (2) or translocation of echinoderm

Correspondence to: Shin-ichi Yamashita, Department of General Thoracic, Breast and Pediatric Surgery, Faculty of Medicine, Fukuoka University, 7-45-1 Nanakuma, Jonanku, Fukuoka 8140180, Japan. Tel: +81 928101011, Fax: +81 928618271, e-mail: yamashi1@fukuoka-u.ac.jp

Key Words: Lung cancer, squamous cell carcinoma, BMI-1, MEL18 , prognosis. microtubule-associated protein-like 4 (EML4)-anaplastic lymphoma kinase (ALK) (3) are known and characterized, yet squamous cell carcinoma, the second most frequent histology, is not well-studied. Although several molecularly targeted therapies have been developed, the benefits of these drugs may contribute to patients with adenocarcinoma but not squamous cell carcinoma. The mechanisms that underlie the carcinogenesis of squamous cell lung cancer are still poorly understood and should be clarified to develop new therapeutic approaches.

Polycomb group (PcG) proteins (discovered in Drosophila as epigenetic gene silencers) are conserved gene silencers playing a crucial role in the development of vertebrate organisms (4). These proteins regulate cell proliferation, senescence and tumorigenesis via well-known growth regulatory pathways. There is increasing evidence that $\mathrm{PcG}$ proteins play an important role in cancer development and recurrence (5). PcG proteins are subdivided into two multimeric protein complexes, that is, the polycomb repressive complex 1 (PRC1) and the polycomb repressive complex 2 (PRC2). The PRC1 complex includes B cellspecific Moloney murine leukemia virus integration site 1 (BMI-1), MEL-18, MPH1/RAE28, M33 and SCMH1 (4-6). BMI-1 is known as a key molecule in repressing p16 $6^{\text {Ink4a }}$ and $\mathrm{p} 19^{\mathrm{Arf}}$, which are encoded by INK4A, for induction of cell growth arrest, senescence and apoptosis. Overexpression of BMI-1 has been found in several human malignancies, such as breast cancer, gastric cancer, colorectal cancer, nasopharyngeal carcinoma, melanoma, oral cancer and bladder cancer, as a poor prognostic factor (6-13).

In addition to BMI-1, mammalian cells express a BMI-1related PcG protein, MEL-18, also known as polycomb group ring finger 2 (PCGF2) (14). BMI-1 and MEL-18, both belonging to the PRC1 complex, exhibit structurally high homology to each other. MEL-18, a BMI-1-related PcG protein, negatively regulates BMI-1 expression and its expression negatively correlates with BMI-1 in proliferating 
Table I. Patients' characteristics.

\begin{tabular}{|c|c|c|c|c|c|c|c|}
\hline Characteristics & All patients & BMI-1-positive & BMI-1-negative & $p$-Value & MEL-18-positive & MEL-18-negative & $p$-Value \\
\hline \multicolumn{8}{|l|}{ Gender } \\
\hline Male & 181 & 40 & 141 & \multirow[t]{2}{*}{0.13} & 44 & 137 & \multirow[t]{2}{*}{0.57} \\
\hline Female & 18 & 1 & 17 & & 3 & 15 & \\
\hline \multicolumn{8}{|l|}{ Age (Years) } \\
\hline$<65$ & 48 & 7 & 41 & \multirow[t]{2}{*}{0.31} & 12 & 36 & \multirow[t]{2}{*}{0.79} \\
\hline$\geq 65$ & 151 & 34 & 117 & & 35 & 116 & \\
\hline \multicolumn{8}{|l|}{ Smoking index } \\
\hline$<400$ & 38 & 9 & 29 & \multirow[t]{3}{*}{0.48} & 9 & 29 & \multirow[t]{3}{*}{0.83} \\
\hline$\geq 400$ & 129 & 23 & 106 & & 29 & 100 & \\
\hline Unknown & 32 & 9 & 23 & & 9 & 23 & \\
\hline \multicolumn{8}{|l|}{ pT } \\
\hline 1 & 45 & 10 & 35 & \multirow[t]{4}{*}{0.49} & 12 & 33 & \multirow[t]{4}{*}{0.39} \\
\hline 2 & 88 & 21 & 67 & & 22 & 66 & \\
\hline 3 & 38 & 7 & 31 & & 5 & 33 & \\
\hline 4 & 28 & 3 & 25 & & 8 & 20 & \\
\hline \multicolumn{8}{|l|}{$\mathrm{pN}$} \\
\hline 0 & 128 & 24 & 104 & \multirow[t]{5}{*}{0.7} & 31 & 97 & \multirow[t]{5}{*}{0.98} \\
\hline 1 & 23 & 5 & 18 & & 5 & 18 & \\
\hline 2 & 40 & 11 & 29 & & 9 & 31 & \\
\hline 3 & 5 & 1 & 4 & & 1 & 4 & \\
\hline Unknown & 3 & 0 & 3 & & 1 & 2 & \\
\hline \multicolumn{8}{|l|}{ Stage } \\
\hline $1 \mathrm{a}$ & 36 & 7 & 29 & \multirow[t]{6}{*}{0.79} & 9 & 27 & \multirow[t]{6}{*}{0.81} \\
\hline $1 b$ & 45 & 10 & 35 & & 12 & 33 & \\
\hline $2 \mathrm{a}$ & 30 & 7 & 23 & & 5 & 25 & \\
\hline $2 b$ & 25 & 3 & 22 & & 4 & 21 & \\
\hline $3 \mathrm{a}$ & 48 & 12 & 36 & & 13 & 35 & \\
\hline $3 b$ & 15 & 2 & 13 & & 4 & 11 & \\
\hline \multicolumn{8}{|c|}{ Adjuvant therapy } \\
\hline$(-)$ & 178 & 34 & 144 & \multirow[t]{2}{*}{0.15} & 41 & 137 & \multirow[t]{2}{*}{0.59} \\
\hline$(+)$ & 21 & 7 & 14 & & 6 & 15 & \\
\hline Total & 199 & 41 & 158 & & 47 & 152 & \\
\hline
\end{tabular}

and senescing human fibroblasts (15). Overexpression of MEL-18 leads to repression of BMI- 1 and reduction of the transformed phenotype in malignant breast cancer cells. Furthermore, the repression of BMI- 1 is accompanied by the reduction of $\mathrm{Akt} /$ protein kinase $\mathrm{B}(\mathrm{PKB})$ activity in breast cancer cells. MEL-18 and BMI-1 may regulate the Akt pathway in breast cancer cells, while MEL-18 functions as a tumor suppressor by repressing the expression of BMI-1 and, consequently, down-regulating Akt activity $(15,16)$.

In this study, we evaluated the association of BMI-1 and MEL-18 expression with clinicopathological factors and prognostic possibility in patients with stage I to III squamous cell lung carcinoma.

\section{Materials and Methods}

Patients and samples. Clinicopathological characteristics of 199 patients with lung squamous cell carcinoma were investigated. Patients diagnosed as stage I to III primary lung squamous cell carcinoma had been surgically resected at the Department of
General Thoracic, Breast and Pediatric Surgery, Fukuoka University School of Medicine and Hospital, Fukuoka, Japan, from January 1, 1995 to December 31, 2005. Our Institutional ethical committee approved the retrospective study and waived the need for patient consent.

We reviewed each patient's medical records for clinical information, including follow-up status and outcome information. Clinicopathological parameters were evaluated, including age, gender, smoking index (the number of cigarettes smoked per day multiplied by the number of years of smoking), tumor size, lymph node (LN) metastasis and adjuvant therapy. The pathological stage was determined according to the tumor/node/metastasis (TNM) classification of malignant tumors (Union for International Cancer Control (UICC)).

Immunohistochemical analysis. BMI-1 and MEL-18 were detected in paraffin sections of lung squamous carcinoma tissue. All slides were interpreted by two independent observers in a blinded fashion. For evaluation reliability, two independent assessors estimated the staining positivity of two serial sections. Four micrometer sections were prepared for tissue slides. Antigen retrieval was performed at $121^{\circ} \mathrm{C}$ for $15 \mathrm{~min}$ in an autoclave with citrate buffer $(\mathrm{pH} \mathrm{9.0)} \mathrm{after}$ 
Table II. Cox regression models for overall survival.

\begin{tabular}{|c|c|c|c|c|c|c|}
\hline \multirow[b]{2}{*}{ Characteristics } & \multicolumn{3}{|c|}{ Univariate analysis } & \multicolumn{3}{|c|}{ Multivariate analysis } \\
\hline & $\mathrm{HR}$ & $95 \% \mathrm{CI}$ & $p$-Value & HR & $95 \%$ CI & $p$-Value \\
\hline $\begin{array}{l}\text { Age } 70<v s .<70 \\
\text { Smoking index }\end{array}$ & 0.91 & $0.61-1.36$ & 0.64 & 1.07 & $0.63-1.79$ & 0.81 \\
\hline $\begin{array}{l}400>v s .400< \\
\text { T factor }\end{array}$ & 2.66 & $1.08-6.56$ & 0.034 & 5.49 & $1.33-22.7$ & 0.02 \\
\hline $\begin{array}{l}\text { T1 vs. T2-4 } \\
\text { Node status }\end{array}$ & 1.32 & $0.82-2.12$ & 0.26 & 1.84 & $1.03-3.3$ & 0.039 \\
\hline $\begin{array}{l}\text { N0 vs. N1-2 } \\
\text { Adjuvant }\end{array}$ & 2.02 & $1.34-3.1$ & 0.001 & 1.8 & $1.01-3.19$ & 0.045 \\
\hline $\begin{array}{l}\text { With } v s . \text { without } \\
\text { BMI-1- }\end{array}$ & 1.19 & $0.64-2.24$ & 0.58 & 0.98 & $0.46-2.12$ & 0.97 \\
\hline $\begin{array}{l}\text { positive } v s \text {. negative } \\
\text { MEL-18- }\end{array}$ & 0.55 & $0.31-0.97$ & 0.04 & 0.56 & $0.27-1.16$ & 0.12 \\
\hline positive $v s$. negative & 0.87 & $0.53-1.43$ & 0.59 & 0.85 & $0.45-1.6$ & 0.85 \\
\hline
\end{tabular}

HR, Hazard ratio; CI, confidence interval.

deparaffinization. DAKO blocking solution (DAKO, Glostrup, Denmark) was used to block non-specific binding. For BMI-1, staining with anti-BMI-1 clone F6 (Millipore, MA, USA) with diluents, 1:300, was performed overnight at $4^{\circ} \mathrm{C}$. After reaction with $3 \%$ hydrogen peroxide for 15 minutes at room temperature, RealTM Envision HRP Rabbit/Mouse antibody (DAKO) for BMI-1 was applied and incubated for $30 \mathrm{~min}$ at room temperature. For MEL18, staining with MEL-18 (H-115) (Santa Cruz Biotechnology, CA USA) with diluents, $1: 100$, was performed overnight at $4^{\circ} \mathrm{C}$. After reaction with $3 \%$ hydrogen peroxide for $15 \mathrm{~min}$ at room temperature, Real ${ }^{\mathrm{TM}}$ Envision HRP Rabbit/Mouse antibody (DAKO) for MEL-18 was applied and incubated for $30 \mathrm{~min}$ at room temperature.

Negative controls were incubated without the primary antibody. IHC staining was evaluated as previously described (17).

Statistical analysis. All statistical analyses were performed using SPSS 14.0 (SPSS Japan Inc., Tokyo, Japan). The different variables of the tumors and normal tissues were analyzed with chi-square tests or Fisher's exact tests. Disease-free and overall survival were analyzed using the Kaplan-Meier method and evaluated by the logrank test. Significant differences were accepted at $p<0.05$.

\section{Results}

Relationship between clinicopathological characteristics, BMI1 and MEL-18 expression. The correlation between the clinicopathological characteristics of pulmonary squamous cell carcinoma and BMI-1 and MEL-18 expression was investigated. A total of 41 of the 199 cases $(21 \%)$ were BMI1-positive. As shown in Table I, no significant correlations between BMI-1 expression and clinicopathological factors were found. The expression pattern of BMI-1 is shown in Figure 1. BMI-1-positive cases showed strong granular staining in the nuclei of pulmonary squamous cell carcinoma from the
Table III. Cox regression models for disease-free survival.

\begin{tabular}{lccc}
\hline & \multicolumn{3}{c}{ Multivariate analysis } \\
\cline { 2 - 4 } Characteristics & HR & $95 \% \mathrm{CI}$ & $p$-Value \\
\hline Age & & & 0.27 \\
$70<$ vs. $<70$ & 0.71 & $0.38-1.3$ & 0.94 \\
$\begin{array}{l}\text { Smoking index } \\
400>v s .400< \\
\text { T factor }\end{array}$ & 0.97 & $0.4-2.33$ & 0.015 \\
$\begin{array}{l}\text { T1 vs. T2-4 } \\
\text { Node status }\end{array}$ & 0.48 & $0.27-0.87$ & 0.014 \\
$\begin{array}{l}\text { N0 vs. N1-2 } \\
\text { BMI-1- } \\
\text { positive } v s . \text { negative } \\
\begin{array}{l}\text { MEL-18- } \\
\text { positive } v s . \text { negative }\end{array}\end{array}$ & 0.97 & $1.16-3.84$ & 0.93 \\
\hline
\end{tabular}

HR, Hazard ratio; CI, confidence interval.

resected specimens, although normal bronchial cells did not show any positive staining of BMI-1. MEL-18 was also stained in the nuclei of pulmonary squamous cell carcinoma specimens (positive: 47 of 199, 23.6\%; Figure 2). However, normal bronchial epithelium was not stained. MEL-18 was related with neither clinicopathological factors nor BMI-1 expression.

Prognostic values of BMI-1 and MEL-18. The possibility of using these proteins to predict the survival of pulmonary squamous cell carcinoma was then examined. Figure 3 shows disease-free, disease-specific and overall survival according to the stratification of BMI-1 expression. The median follow-up period was 63 months. Five-year diseasefree survival in the BMI-1-positive group was better than in the negative group $(78.4 \%$ and $63.8 \%$, respectively, $p=0.045$; Figure $3 \mathrm{~A}$ ). However, five-year disease-specific survival showed a trend of better survival in the BMI-1-positive group (positive $71.2 \%$, negative $57.4 \%, p=0.08$; Figure 3B). Five-year overall survival, including other causes of death, showed significant difference between the two groups (positive 66.8\%, negative $45.5 \%, p=0.04$; Figure $3 \mathrm{C}$ ). On the other hand, MEL-18 showed prognostic significance in neither disease-free, nor disease-specific, nor overall survival ( $p=0.15, p=0.54$ and $p=0.59$, respectively; Figures 4A-C). We found that smoking index, nodal involvement and BMI1 expression showed prognostic significance by univariate analysis in overall survival (Table II); however, only the smoking index, $\mathrm{T}$ factor and nodal involvement showed significant prognostic value by multivariate Cox regression analysis. BMI-1 expression showed a potential for prognostic impact by multivariate analysis (Table II). Multivariate analysis in disease-free survival showed that $\mathrm{T}$ factor and 

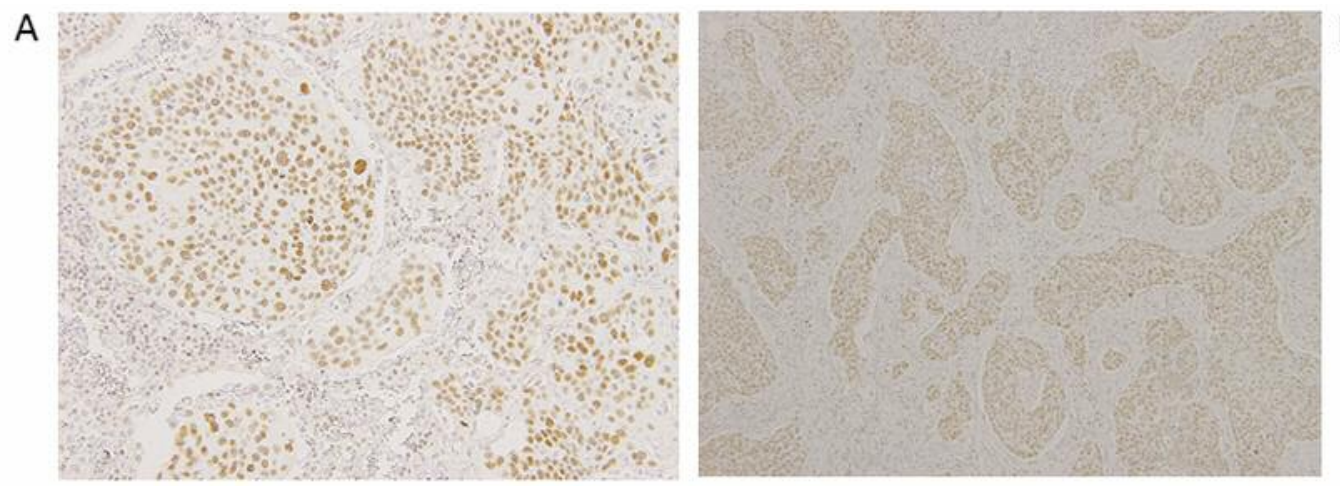

C
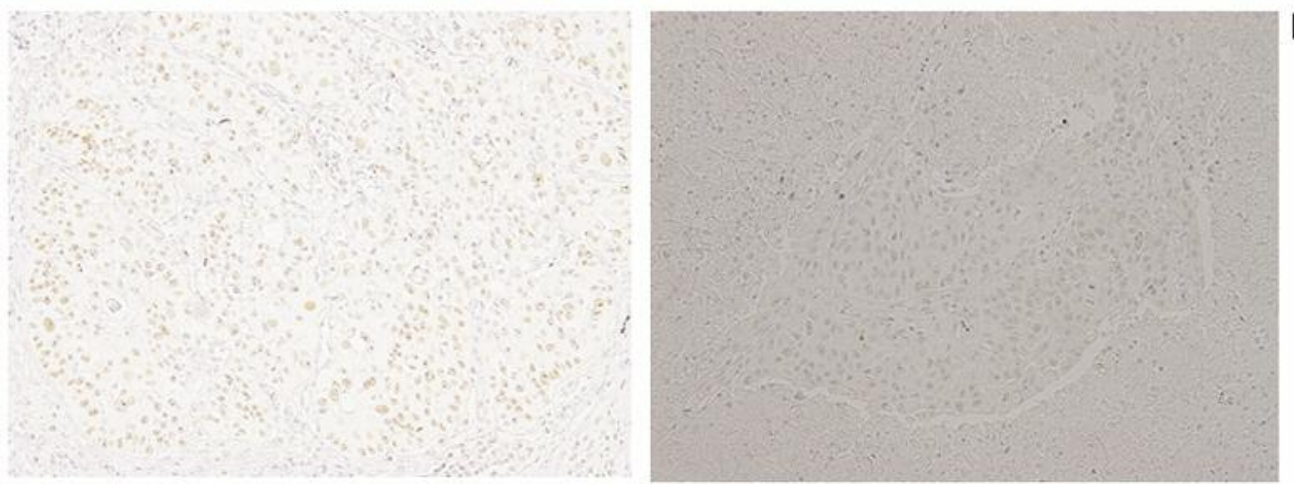

D

Figure 1. Representative BMI-1 protein expression in pulmonary squamous cell carcinoma by immunohistochemistry (IHC). Nuclei of cancer cells were stained strongly in $3+$ cases $(200 \times, A), 2+(B)$ and $1+(C)$. Negative staining of pulmonary squamous cell carcinoma $(D)$.
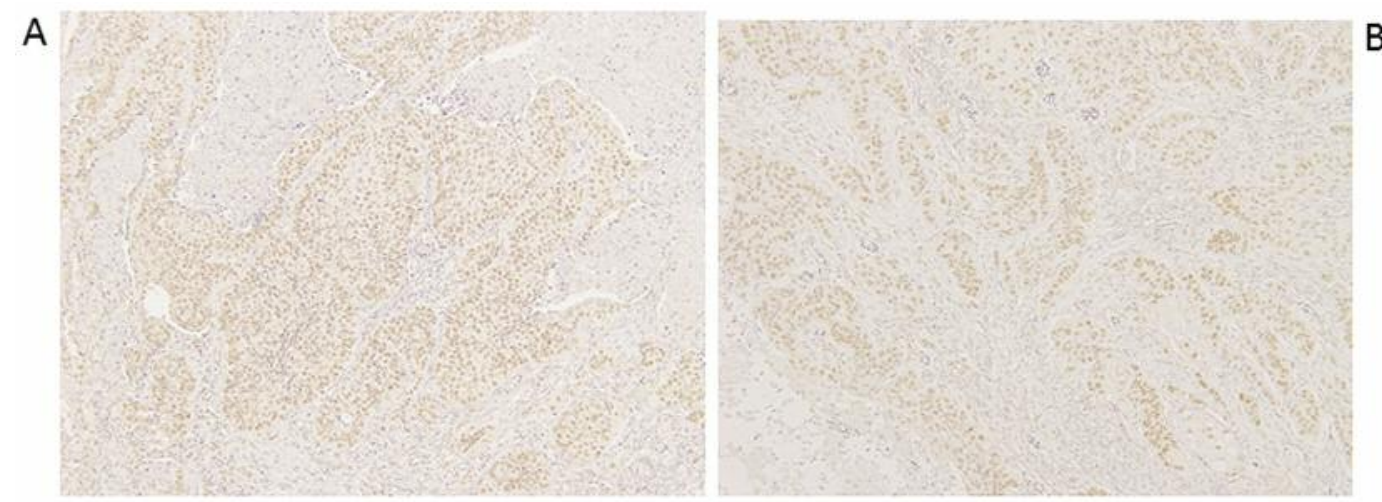

$\mathrm{C}$

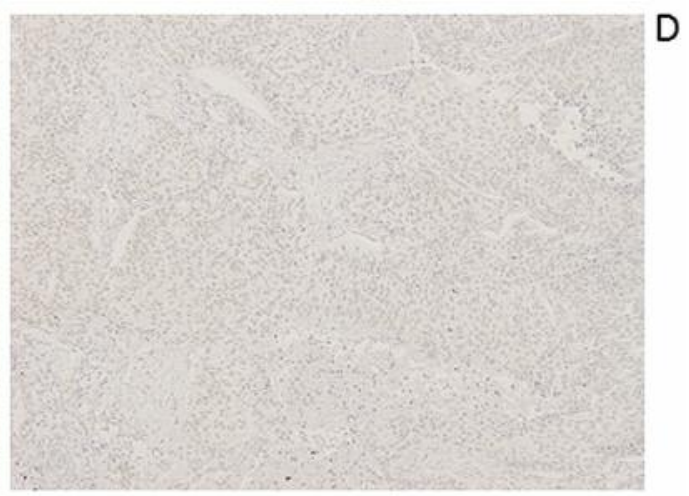

Figure 2. Representative MEL-18 protein expression in pulmonary squamous cell carcinoma by immunohistochemistry (IHC). Nuclei of cancer cells were stained strongly in $3+$ cases $(200 x, A), 2+(B)$ and $1+(C)$. Negative staining of pulmonary squamous cell carcinoma $(D)$. 

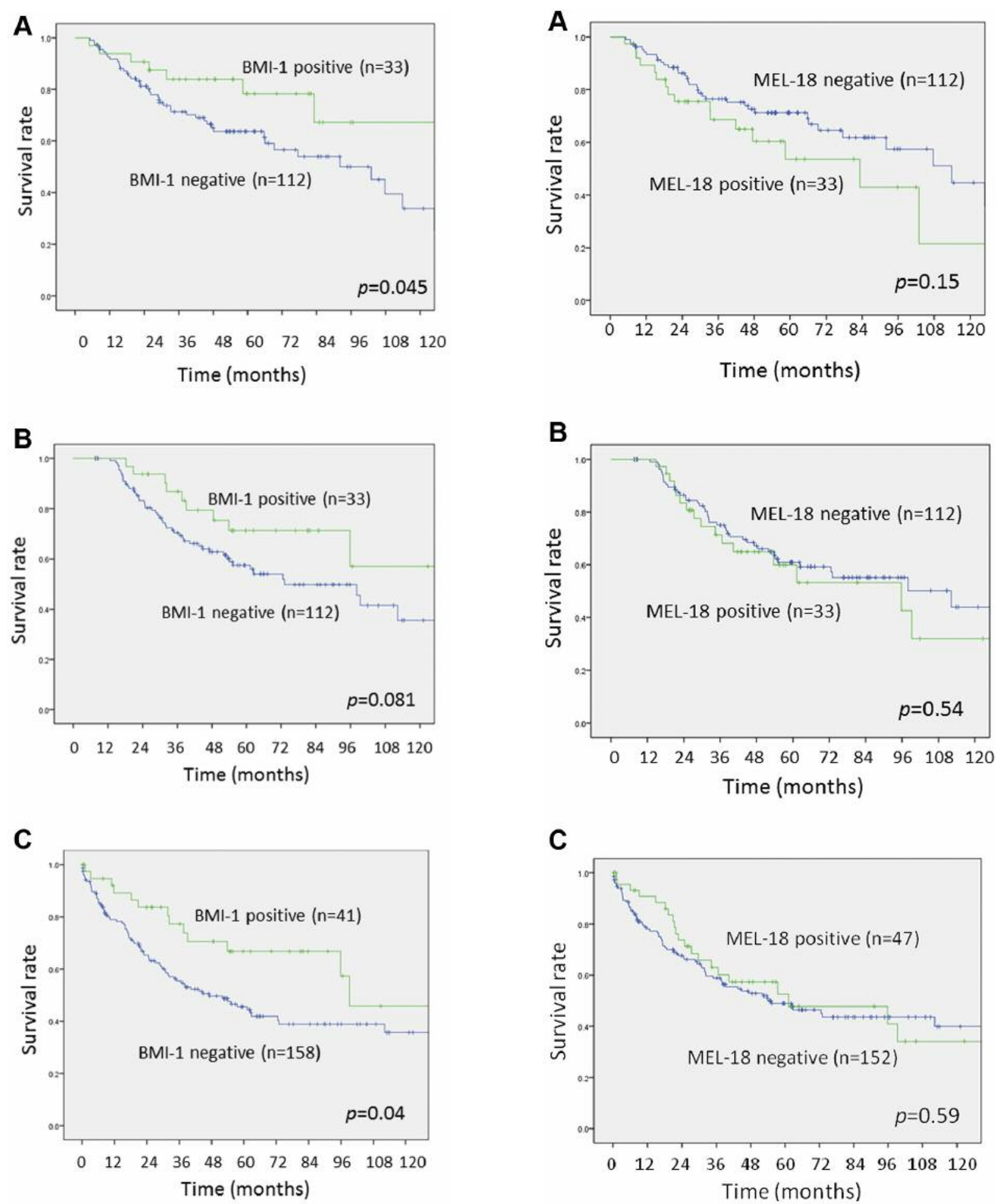

Figure 3. Disease-free survival $(A)$, disease-specific survival $(B)$ and overall survival $(C)$ according to BMI-1 protein expression. Five-year disease-free survival was $78.4 \%$ in the BMI-1-positive group and $63.8 \%$ in negative group $(p=0.045)$. Five-year disease-specific survival was $71.2 \%$ in the BMI-1-positive group and $57.4 \%$ in the negative group ( $p=0.08$ ). Five-year overall survival was $66.8 \%$ in BMI-1-positive group and $45.5 \%$ in thenegative group $(p=0.04)$.

Figure 4. Disease-free survival (A), disease-specific survival (B), and overall survival $(C)$ according to MEL-18 protein expression. Five-year disease-free survival was $53.6 \%$ in the MEL-18-positive group and $71.2 \%$ in the negative group $(p=0.15)$. Five-year disease-specific survival was $59.9 \%$ in the MEL-18-positive group and $60.9 \%$ in negative group $(p=0.54)$. Five-year overall survival was $54.2 \%$ in the $M E L-18$-positive group and $47.9 \%$ in the negative group $(p=0.59)$. 
nodal status were significant prognostic factors; BMI-1 and MEL-18 were not (Table III).

\section{Discussion}

BMI-1 is one of the proteins that is a member of the polycomb group family and has a potentially critical role for tumor progression (5). BMI-1 is known as an oncogene that has a critical role associated with $C-M Y C$ in B-cell lymphoma cells (15). Most studies have shown that overexpression of BMI-1 is associated with poor prognosis in many human cancers, including cervical, breast, lung, esophageal, stomach and colon $(6-9,16,18,19)$. However, the opposite result, that BMI-1 may be a favorable prognostic factor in breast cancer, was also reported (20). It has been shown that BMI-1 is significantly correlated with negative axillary node metastasis and estrogen receptor (ER) status; furthermore, prognosis in BMI-1-positive cases is significantly more favorable than in negative cases. The suggested reason was that comparable methods of IHC for expression levels of BMI-1 were different in the evaluation process, including distribution and intensity of positive cells between the two studies. Saeki $e t$ al. reported that BMI-1 mRNA expression was inversely correlated with nodal involvement and staging in breast cancer. These results suggested that BMI-1 may cause carcinogenesis in early events, but not late stage progression, but this remains controversial. Another study of BMI-1 expression in lung cancer showed significant correlation with early and decline in late stages of disease, which is negatively correlated with nodal involvement (18). They reported that silencing of BMI-1 expression induced invasiveness and metastasis in human lung cancer cell lines in vitro. These results support our results that the staging of lung squamous cell cancer was not correlated with BMI-1 expression. It has also been reported that BMI-1 repression induces epithelialmesenchymal transition and progression of lung cancer in vitro. In our study, overall survival in lung squamous cell carcinoma was inversely correlated with BMI-1 expression, and these results were supported by a previous report (18). In another report, $B M I-1$ mRNA expression in early stage breast cancer was higher than in late stage and was inversely related with lymph node metastasis (21). Taken together, BMI-1 expression may play a crucial role in carcinogenesis but not progression in lung cancer.

In this study, we focused on the expression of BMI-1 in squamous cell carcinoma but not adenocarcinoma. The prognostic value of BMI-1 was evaluated and positive BMI1 expression was a favorable prognostic factor in squamous cell lung cancer. Multivariate analysis showed that smoking index, $\mathrm{T}$ factor and nodal status were of significant value for overall survival but the value of BMI-1 was weak. These well-known confounding factors affected prognosis in our study; however, BMI-1 may be a weak independent prognostic factor. Furthermore, disease-free survival was associated with BMI-1 expression but weakly related with disease-specific survival. The reason why this discrepancy between overall and disease-specific survival existed remains unclear. A possible reason is that other causes of death, such as pneumonia because of a high prevalence of smoking, affected the analysis. Most studies about BMI-1 in lung cancer were estimated in adenocarcinoma or non-small cell carcinoma (22-24). The function of BMI-1 in pulmonary squamous cell carcinoma may be different from in adenocarcinoma of the lung. Although there are several driver mutations, such as EGFR of lung adenocarcinoma, squamous cell carcinoma of the lung is neither well-known nor characterized. BMI-1 may be one of the critical functions for carcinogenesis and should be studied in a larger population.

MEL-18, which was inversely expressed with BMI-1, was evaluated in our study. However, no correlation with any clinicopathological factors was shown and it did not have any prognostic value in this study. MEL-18 is a regulator of cell proliferation and quittance by BMI-1 suppression acting as a tumor suppressor gene or oncogene (15). The reason why our study showed no correlation between the two proteins is unknown.

The limitations of this study are that it involves retrospective analysis and is a single-Institution study. Another limitation is the relatively small number of patients used to observe differences in survival between the two groups. Longer follow-up and an increased number of patients in both groups may lead to further confirmation of the results.

In conclusion, BMI-1 protein was expressed in pulmonary squamous cell carcinoma and may be a possible prognostic marker. Further studies should be undertaken to clarify this hypothesis.

\section{Acknowledgements}

The Authors appreciate the technical support of Ms. Yoko Miyanari.

\section{References}

1 International Agency for Research on Cancer. World cancer report, 2014. Lyon, France: World Health Organization, International Agency for Research on Cancer, 2014.

2 Paez JG, Jänne PA, Lee JC, Tracy S, Greulich H, Gabriel S, Herman P, Kaye FJ, Lindeman N, Boggon TJ, Naoki K, Sasaki H, Fujii Y, Eck MJ, Sellers WR, Johnson BE and Meyerson M: EGFR mutations in lung cancer: Correlation with clinical response to gefitinib therapy. Science 304: 1497-1500, 2004.

3 Soda M, Choi YL, Enomoto M, Takada S, Yamashita Y, Ishikawa S, Fujiwara S, Watanabe H, Kurashina K, Hatanaka H, Bando M, Ohno S, Ishikawa Y, Aburatani H, Niki T, Sohara Y, Sugiyama $\mathrm{Y}$ and Mano H: Identification of the transforming EML4-ALK fusion gene in non-small-cell lung cancer. Nature 448: 561-566, 2007. 
4 Siddique HR and Saleem M: Concise Review: Role of BMI1, a stem cell factor, in cancer recurrence and chemoresistance: Preclinical and clinical evidences. Stem Cells 30: 372-378, 2012.

5 Jacobs JJ, Kieboom K, Marino S, DePinho RA and van Lohuizen M: The oncogene and Polycomb group gene bmi-1 regulates cell proliferation and senescence through the ink $4 \mathrm{a}$ locus. Nature 397: 164-168, 1999.

6 Zhang XW, Sheng YP, Li Q, Qin W, Lu YW, Cheng YF, Liu BY, Zhang FC, Li J, Dimri GP and Guo WJ: BMI1 and Mel-18 oppositely regulate carcinogenesis and progression of gastric cancer. Molecular Cancer 9: 40, 2010.

7 Kim JH, Yoon SY, Jeong SH, Kim SY, Moon SK, Joo JH, Lee Y, Choe IS and Kim JW: Overexpression of Bmi-1 oncoprotein correlates with axillary lymph node metastases in invasive ductal breast cancer. Breast 13: 383-388, 2004.

8 Liu JH, Song LB, Zhang X, Guo BH, Feng Y, Li XX, Liao WT, Zeng MS and Huang KH: Bmi-1 expression predicts prognosis for patients with gastric carcinoma. J Surg Oncol 97: 267-272, 2008.

9 Kim JH, Yoon SY, Kim CN, Joo JH, Moon SK, Choe IS, Choe YK and Kim JW: The Bmi-1 oncoprotein is overexpressed in human colorectal cancer and correlates with the reduced p16INK4a/p14ARF proteins. Cancer Lett 203: 217-224, 2004.

10 Song LB, Zeng MS, Liao WT, Zhang L, Mo HY, Liu WL, Shao JY, Wu QL, Li MZ, Xia YF, Fu LW, Huang WL, Dimri GP, Band $\mathrm{V}$ and Zeng YX: Bmi-1 is a novel molecular marker of nasopharyngeal carcinoma progression and immortalizes primary human nasopharyngeal epithelial cells. Cancer Res 66: 62256232, 2006.

11 Mihic-Probst D, Kuster A, Kilgus S, Bode-Lesniewska B, Ingold-Heppner B, Leung C, Storz M, Seifert B, Marino S, Schraml P, Dummer R and Moch H: Consistent expression of the stem cell renewal factor BMI-1 in primary and metastatic melanoma. Int J Cancer 121: 1764-1770, 2007.

12 Kang MK, Kim RH, Kim SJ, Yip FK, Shin KH, Dimri GP, Christensen R, Han T and Park NH: Elevated Bmi-1 expression is associated with dysplastic cell transformation during oral carcinogenesis and is required for cancer cell replication and survival. Br J Cancer 96: 126-133, 2007.

13 Qin ZK, Yang JA, Ye YL, Zhang X, Xu LH, Zhou FJ, Han H, Liu ZW, Song LB and Zeng MS: Expression of Bmi-1 is a prognostic marker in bladder cancer. BMC Cancer 9: 61-67, 2009.

14 Ishida A, Asano H, Hasegawa M, Koseki H, Ono T, Yoshida MC, Taniguchi $\mathrm{M}$ and Kanno $\mathrm{M}$ : Cloning and chromosome mapping of the human Mel-18 gene which encodes a DNAbinding protein with a new 'RING-finger' motif. Gene 129: 249255,1993 .
15 Guo WJ, Datta S, Band V and Dimiri GP: Mel-18, a polycomb group protein, regulates cell proliferation and senescence via transcriptional repression of Bmi-1 and c-Myc oncoproteins. Mol Biol Cell 18: 536-546, 2007.

16 Guo WJ, Zeng MS, Yadav A, Song LB, Guo BH, Band V and Dimri GP: Mel-18 acts as a tumor suppressor by repressing Bmi1 expression and down-regulating Akt activity in breast cancer cells. Cancer Res 67: 5083-5089, 2007.

17 Enomoto Y, Yamashita S, Yoshinaga Y, Fukami Y, Miyahara S, Nabeshima K and Iwasaki A: Downregulation of DYRK2 can be a predictor of recurrence in early-stage breast cancer. Tumour Biol 35: 11021-11025, 2014.

18 Xiong D, Ye Y, Fu Y, Wang J, Kuang B, Wang H, Wang X, Zu $\mathrm{L}$, Xiao $\mathrm{G}$, Hao $\mathrm{M}$ and Wang $\mathrm{J}$ : Bmi-1 expression modulates non-small cell lung cancer progression, Cancer Biol Ther 16: 756-763, 2015.

19 Vrzalikova K, Skarda J, Ehrmann J, Murray PG, Fridman E, Kopolovic J, Knizetova P, Hajduch M, Klein J, Kolek V, Radova $\mathrm{L}$ and Kolar Z: Prognostic value of Bmi-1 oncoprotein expression in NSCLC patients: A tissue microarray study. J Cancer Res Clin Oncol 134: 1037-1042, 2008.

20 Choi YJ, Choi YL, Cho EY, Shin YK, Sung KW, Hwang YK, Lee SJ, Kong G, Lee JE, Kim JS, Kim JH, Yang JH and Nam SJ: Expression of Bmi-1 protein in tumor tissues is associated with favorable prognosis in breast cancer patients. Breast Cancer Res Treat 113: 83-93, 2009.

21 Saeki M, Kobayashi D, Tsuji N, Kuribayashi K and Watanabe $\mathrm{N}$ : Diagnostic importance of overexpression of Bmi-1 mRNA in early breast cancers. Int J Oncol 35: 511-515, 2009.

$22 \mathrm{Hu} \mathrm{J}$, Liu YL, Piao SL, Yang DD, Yang YM and Cai L: Expression patterns of USP22 and potential targets BMI-1, PTEN, p-AKT in non-small-cell lung cancer. Lung Cancer 77: 593-599, 2012.

23 Zhang X, Sun J, Wang H, Lou Y, Zhang Y, Sha H, Feng J and Han B: IGF-1R and Bmi-1 expressions in lung adenocarcinoma and their clinicopathologic and prognostic significance. Tumour Biol 35: 739-745, 2014.

24 Kikuchi J, Kinoshita I, Shimizu Y, Kikuchi E, Konishi J, Oizumi S, Kaga K, Matsuno Y, Nishimura M and Dosaka-Akita H: Distinctive expression of the polycomb group proteins Bmil polycomb ring finger oncogene and enhancer of zeste homolog 2 in non-small cell lung cancers and their clinical and clinicopathologic significance. Cancer 116: 3015-3024, 2010.

Received February 22, 2017

Revised March 14, 2017

Accepted March 15, 2017 